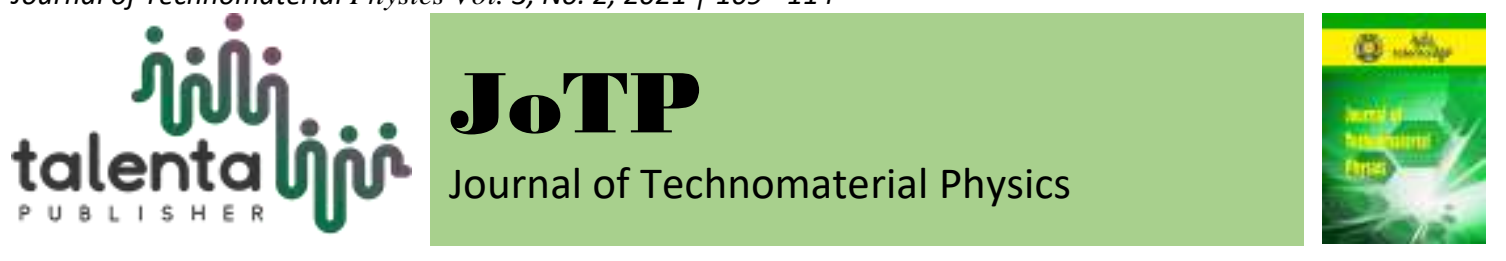

\title{
Battery on Carburization ST 37 Steel
}

\author{
Melya Dyanasari Sebayang ${ }^{I^{*}}$ \\ ${ }^{I}$ Department of Mechanical Enginering, Faculty of Engineering, Universitas Kristen Indonesia, \\ Jl.Mayjen Sutoyo No. 1 Cawang-Jakarta Timur, Indonesia
}

\begin{abstract}
A surface hardening process by adding carbon to its surface without changing the core properties of the material is called the carburization process. This process is carried out at the austenite temperature so that the carbon can diffuse into the phase. This process can only be done on low carbon steels with a content of below $0.25 \%$. This research uses ST 37 steel which is a low content steel with a carbon content of $0.18 \%$. This type of steel is surface hardened with a carburizing temperature of $850^{\circ} \mathrm{C}$ for a long lasting time of 1 hour, then it is carried out under moderate cooling with outside air media. This research produces a carburizing method with carbon battery media that easily breaks down into steel, which occurs in carbon batteries at temperatures below $723^{\circ} \mathrm{C}$. And change its mechanical properties from the comparison of the initial mechanical properties of the specimen. Carburizing with battery rock media is more efficient at temperatures below $723^{\circ} \mathrm{C}$. Because of at temperatures below austenite or below the carburizing temperature of carbon from the batteries, it can absorb the surface of the steel even though the amount is still very small. Because the temperature is below the austenite temperature, the absorbed carbons cannot diffuse as happened in the carburization process, but the absorbed carbons can bind the grain boundaries so that they change their hardness by $4 \%$. The microstructure in the research that occurs in this process has nothing to change its phase because the temperature does not reach the austenite temperature.
\end{abstract}

Keyword: carburizing process, ST 37 steel, battery.

Received 09 August 2021 | Revised [20 August 2021] | Accepted [27 August 2021]

\section{Introduction}

In the use of metal components often experience things that are not desired, such as cracks that cause breakage, or wear which causes relatively short life of components. To overcome this, a heat treatment process is needed. Heat treatment basically consists of several stages, starting from heating to a certain temperature, holding for a while, and continuing with a certain speed [1-2].

The human need for metal materials is increasing and the demand is very high, because metal materials are widely used for the needs of the automotive industry such as gears, chains and other machine components [3-4]. Therefore, humans are required to be more creative and innovative in metal development. As an answer to the demands of the market who want quality

\footnotetext{
*Corresponding author at: Jl.Mayjen Sutoyo No. 1 Cawang-Jakarta Timur, Indonesia

E-mail address: melcan_sebayang@yahoo.co.id
} 
metal products so that the use of these metal component products can last a long time. The process of heat treatment of steel components by diffusing chemical elements on the surface [56]. One of the heat treatment processes that can be carried out is the carburization process in which the specimen is heated and the carbon content is added so that its mechanical properties can be changed. In this process the carbon element is added only in the outer layer so that hardness is obtained on the surface of the carburized specimen.

\section{Methods}

\subsection{Hardness methods}

The purpose of hardness testing is to determine the mechanical properties of the hardness of the specimen being tested, so there are three specimens to be tested, namely; Initial specimen ST37, ST 37 carburized with coconut shell charcoal [7-8].

\subsection{Tensile Methods}

Tensile testing is carried out to assess the tensile strength, upstream strength, and elongation [910]. The specimen to be tested is installed in a tensile testing machine where the two ends of the specimen are clamped to be pulled with the same tensile load in both directions of the specimen to be tested [11-12].

\subsection{Elongation Methods}

The tensile strength test is performed using a tensile testing machine with a maximum capacity of 30,000 kgf. For each variation, the test is carried out 4 times so because there are 3 variations, there are 12 specimens for the tensile test [13-14].

\subsection{Microstructure Methods}

Micro-testing is carried out to observe the microstructure after the carburization process for varying holding time variables, the microstructure testing tool is carried out on the cross-section of the test object [15]. The test object is cut perpendicular to the surface undergoing the heat treatment process using a hacksaw. Cooling water is applied during cutting to prevent changes in the structure of the sample. The test object that has been cut is then mounted with resin and the specimen is prepared, namely starting with sanding from coarse to fine. Then polished with a velvet cloth which is given toothpaste as a smoothener [16-18]. The polished specimen is then etched. After the above process is complete, a photo shoot is carried out using SEM (Scanning Electron Microscope) [19-20]. 


\subsection{Research Flowchart}

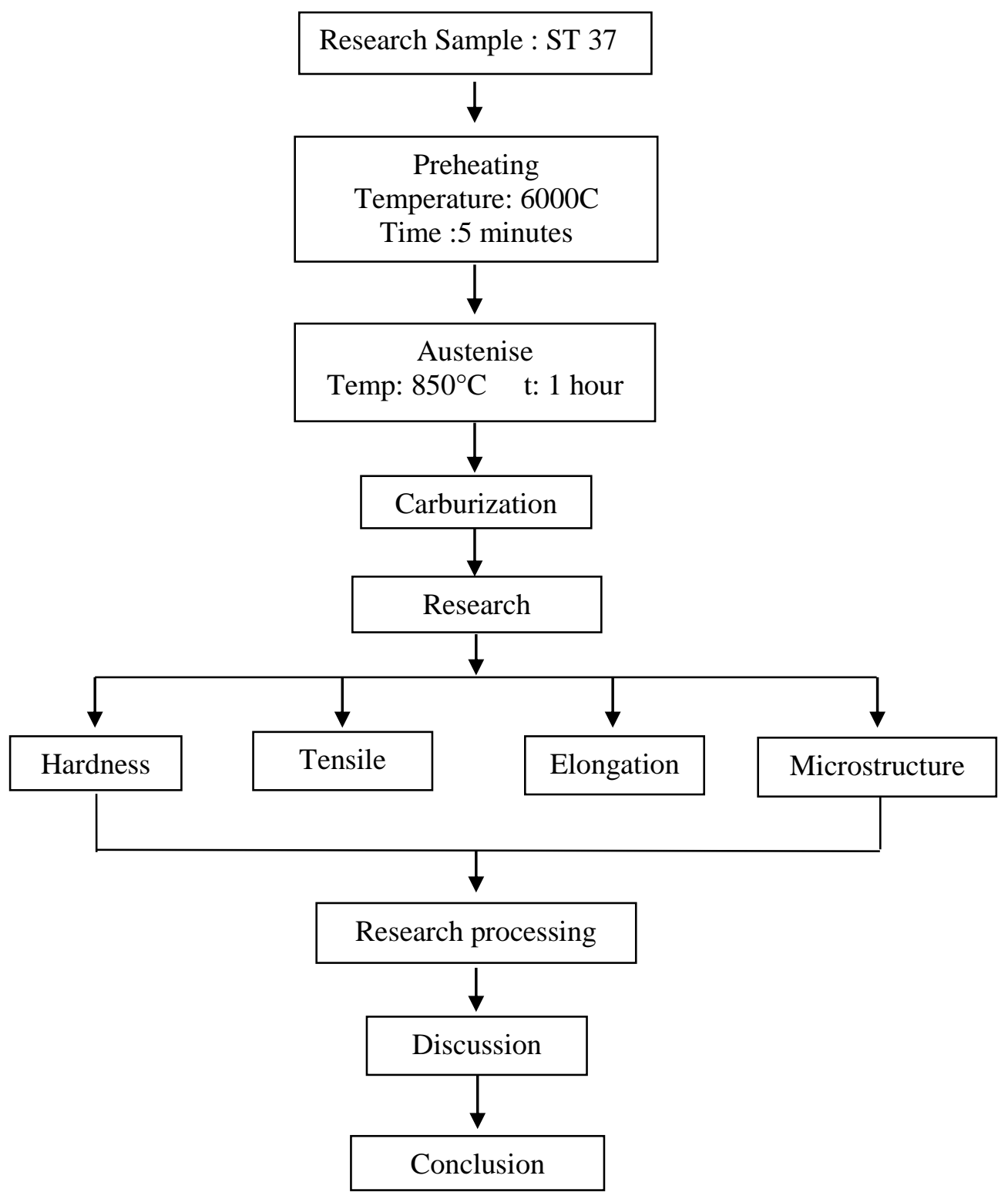

Figure 1. Research flowchart

\section{Result and Discussion}

Solid carburization heat treatment process carried out on ST37 steel material with a long lasting time of 1 hour. After that the specimens were cooled with air media or (Normalizing). Then the specimen will be tested so that the analyzed data can be obtained so that mechanical properties and microstructure can be obtained that are different from the original properties of the specimen before carburizing.

\subsection{Hardness Analysis}

Carburizing process on tensile strength values. In the initial material the tensile strength value with a value of $425.22 \mathrm{~N} / \mathrm{mm}^{2}$, an increase occurred in the specimens with carburized rock batteries but not too big from the initial specimens, only up $4.2 \%$ with a value of $443.45 \mathrm{~N} / \mathrm{mm}^{2}$. The increase in the value of carburization in the battery is due to the fact that carbon can 
decompose on the surface of the steel so that the tensile strength can increase even though the percentage is very small because the temperature does not reach austenite so that the decomposed carbon cannot transform into phase, but the carbon trapped in the steel sticks to the grain boundaries so that its hardness was up $4 \%$ from the initial specimen.

\subsection{Elongation Point Analysis}

The elongation value in the carburization process with the battery, the elongation value is not much different from the initial specimen.

\subsection{Microstructure Analysis}

In the initial specimens, the phase content formed by ferrite + pearlite can be seen in the SEM photos. With the initial goal of the carburization process is to add carbon content to the surface of the steel so that it can change the phase to pearlite on the steel surface, but due to trouble in the heating kitchen so that the desired temperature is not achieved. So that the phase change cannot occur, this is because carbon cannot diffuse with the atoms in the phase content. In the carburizing carbon media can permeate the surface of the steel even though the value is still very small and cannot increase the surface hardness high because the absorbed carbon can only be attached to the surface of the steel. grain boundaries so that the hardness value increased $4 \%$ from the initial specimen.

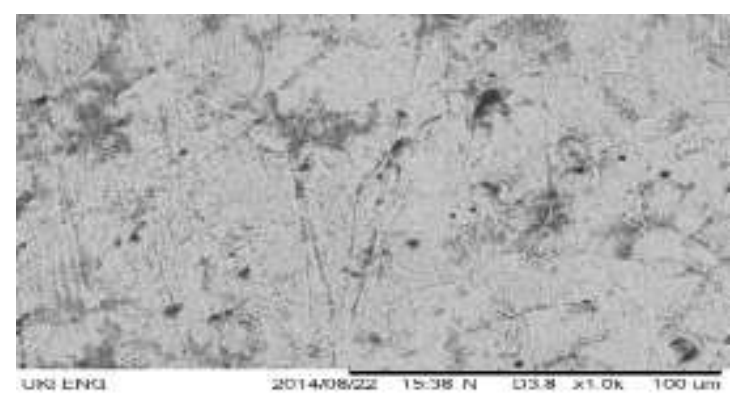

Figure 2. ST37 steel microstructure (1000 x magnification)

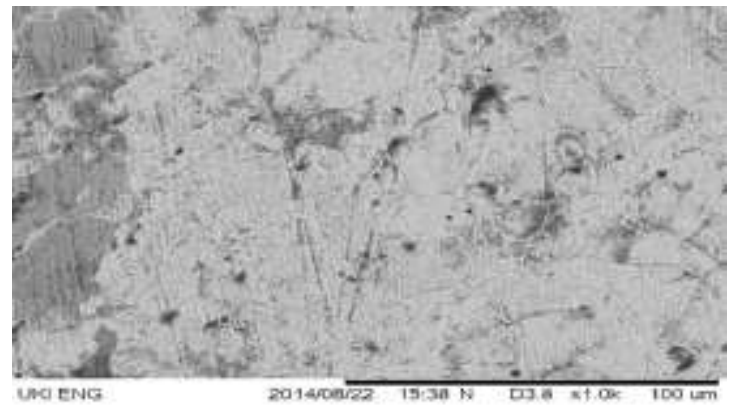

Figure 3. Microstructure of ST 37 steel carburized battery with $1000 \mathrm{x}$ magnification 


\section{Conclusion}

Based on the results of the analysis obtained from the results of research on the carburization value of coconut shell charcoal media on the mechanical properties of low carbon steel ST 37, the following conclusions can be drawn:

1. From the research data, it can be concluded that carburization with battery media is more efficient than coconut shell charcoal at temperatures below $723^{\circ} \mathrm{C}$. Because at temperatures below austenite or below the carburizing temperature, the carbon from the rock can absorb the surface of the steel even though the amount is still very small. Because the temperature is below the austenite temperature, the absorbed carbons cannot diffuse as happened in the carburization process, but the absorbed carbons can bind the grain boundaries so that they change their hardness by $4 \%$.

2. In the microstructure research that occurs in this process, nothing can change its phase because the temperature does not reach the austenite temperature. In the carburization process with the battery media on the microstructure, it appears that there is decomposition of carbon on the steel surface but the amount is still very small so that it does not have a significant impact on surface hardening of the steel carried out by the study.

\section{REFERENCES}

[1] S. P. Schneider, Tools in Jeanne Mager Stellman, Chemical, Industries and Occupations. Encyclopaedia of Occupational Health and Safety III, $4^{\text {th }}$ edition, Geneva: International Labour Office, 1998.

[2] K. H. Prabhudev, Handbook of Heat Treatment of Steels, New Delhi: Tata McGraw-Hill Publishing Company Limited, 1988.

[3] H. C. Mercer, Ancient Carpenters' Tools: Illustrated and Explained, Together with the Implements of the Lumberman, Joiner and Cabinet-Maker in Use in the Eighteenth Century, New York: Dover Publications, INC, 1960.

[4] T. H. C. Childs, Mechanical Design $2^{\text {nd }}$ Edition, Oxford: Elsevier, 2004.

[5] K. Kostyk, M. Hatala, V. Kostyk, V. Ivanov, I. Pavlenko and D. Duplakova, "Simulation of Diffusion Processes in Chemical and Thermal Processing of Machine Parts," Processes, vol. 9, no. 4, 698, pp. 1-14, 2021.

[6] K. Kostyk, "Development of Innovative Method of Steel Surface Hardening by A Combined Chemical-Thermal Treatment," EUREKA: Physics and Engineering, vol. 6, pp. 46-52, 2016.

[7] Sularso and K. Suga, Dasar Perencanaan dan Pemilihan Elemen Mesin, Jakarta: PT. Pradnya Paramita, 2004.

[8] H. Chandler, Hardness Testing, ASM international, 1999.

[9] G. V. Samsonov, Mechanical Properties of the Elements in Handbook of the Physicochemical Properties of the Elements, New York: Springer, 1968.

[10] J. M. Seitz, E. Wulf, P. Freytag, D. Bormann and F. W. Bach, "The Manufacture of Resorbable Suture Material From Magnesium," Advanced Engineering Materials, vol. 12, no. 11, pp. 1099-1105, 2010.

[11] A. Bardelcik, C. P. Salisbury, S. Winkler, M. A. Wells and M. J. Worswick, "Effect of Cooling Rate on High Stain Rate Properties of Boron Steel," International Journal of 
Impact Engineering, vol. 37, no. 6, pp. 694-702, 2010.

[12] P. Schubertl, "Tensile and Flexural Strength of Masonry-Influences, Test Methods, Test Results," Stress, vol. 50, no. 2, pp. 895-907, 1994.

[13] International Union of Pure and Applied Chemistry (IUPAC), Conventional Atomic Weights 2013. Commission on Isotopic Abundances and Atomic Weights, 2013.

[14] A. Imamura and Y. Aoki, "An Elongation Method to Calculate the Electronic Structure of Non-Periodical and Periodical Polymers," Advances in Colloid and Interface Science, vol. 71-72, pp. 147-164, 1997.

[15] M. D. Sebayang, "ST37 Steel Carburization with Coconut Charcoal," Journal of Technomaterials Physics, vol. 3, no. 1, pp. 29-35, 2021.

[16] M. D. Sebayang, S. M. Yudo and C. Silitonga, "Effect of Heat Treatment on Microstructure of Steel AISI 01 Tools," in IOP Conference Series: Materials Science and Engineering, vol. 343, no. 1, 012005, IOP Publishing, 2018.

[17] A. A. Kaya, P. Krauklis and D. J. Young, "Microstructure of HK40 Alloy After High Temperature Service in Oxidizing/Carburizing Environment: I. Oxidation Phenomena and Propagation of A Crack," Materials Characterization, vol. 49, no. 1, pp. 11-21, 2002.

[18] K. Hu, G. Wang, X. Li and S. Qu, "Microstructure and Formation Mechanism in A Surface Carburized Tungsten Heavy Alloy," Journal of Alloys and Compounds, vol. 787, pp. 560-569, 2019.

[19] M. D. Sebayang and A. G. Gultom, "Studi Analisa Material dan Desain Produk Perkakas Tangan," in Seminar Nasional Sains dan Teknologi (SAINTEK) II, 7-8 September 2017, Malang, 2017.

[20] A. A. Kaya, "Microstructure of HK40 Alloy After High-Temperature Service in Oxidizing/Carburizing Environment: II. Carburization and Carbide Transformations," Materials Characterization, vol. 49, no. 1, pp. 23-34, 2002. 